\title{
Outcomes of medical malpractice claims in assisted reproductive technology over a 10-year period from a single carrier
}

\author{
Gerard Letterie ${ }^{1}$ (D)
}

Received: 3 November 2016 / Accepted: 27 January 2017 /Published online: 11 February 2017

(C) Springer Science+Business Media New York 2017

\begin{abstract}
Objective Medical malpractice claims vary by specialty. Contributory factors to malpractice in reproductive endocrinology and infertility (REI) are not well defined. We sought to determine claims' frequency, basis of claims, and outcomes of settled claims in REI.

Design This is a retrospective, descriptive review of 10 years of claims.

Setting The setting is private practices.

Materials and methods Claims were monitored within one malpractice carrier between 2006 and 2015 covering 10 practices and 184,015 IVF cycles. Total claims, basis of claims, and indemnity paid were evaluated.

Results There were 176 incidents resulting in 30 settled claims with indemnity payments in 21 . Categories of claims settled included misdiagnosis $(N=4)$, lack of informed consent $(N=5)$, embryology errors $(N=8)$, and surgical complications $(N=4)$. Total and average awards were $\$ 15,062,000$ and $\$ 717,238$, respectively. Misdiagnosis and lack of informed consent had highest total award amount at $\$ 11,583,000$ accounting for $76 \%$ of award dollars. The two highest awards were $\$ 4.5$ million and $\$ 3.0$ million for cancer and genetic misdiagnosis, respectively. Excluding these two awards, payments totaled $\$ 7,562,000$, ranged from $\$ 6000$ to $\$ 900,000$ and averaged $\$ 170,363$. Errors in handling of embryos were highest in frequency accounting for $38 \%$ of claims paid for a total of $\$ 1,593,000$ with average payment of $\$ 199,188$. Settlements for surgical complications totaled $\$ 1,855,000$ and averaged $\$ 463,750$ per claim.
\end{abstract}

Gerard Letterie

gerard.letterie@integramed.com

1 Seattle Reproductive Medicine, 1505 Westlake Suite 400, Seattle, WA 981105, USA
Conclusions Misdiagnosis and lack of informed consent are the highest award categories. Embryology lab errors are the most frequent causes of claims with the lowest award per settlement. The average cost for claims settled is relatively high compared to settlements in other specialties.

Keywords Medical malpractice $\cdot$ Misdiagnosis $\cdot$ Medical error · Claim settlements

\section{Introduction}

The contemporary medical malpractice system of torts and litigation is a complex and by some opinions, dysfunctional system [1]. The medical and legal communities continue diligent work to improve the environment for providers and patients alike by identifying areas of high risk. The process of studying claims and settlements provides insight into areas of practice that may require adjustment either in delivery or in counseling across and within specialties. Risk management and root cause analysis are analytic tools to achieve these goals [2,3]. Risk profiles and claim experiences among major specialties such as surgery, anesthesia, and obstetrics are well profiled [4]. The profiles have been informative in detailing plans of risk reduction and better patient care.

The distribution of claims and outcomes among reproductive endocrinology and infertility (REI) practices and practitioners is not well defined. A better understanding of past and emerging trends of claims in REI could identify areas of vulnerability and result in management, treatment and counseling that better serve patient and provider interests alike. If one area of REI practice for example accounts for a significant number of claims or disproportionately high settlement amount, the ability to identify such areas would be important. 
We studied paid malpractice claims in REI practices. Our objective is to describe details of claims, settlements, and amount paid to gain insight into the medical malpractice climate for practices involved in REI.

\section{Materials and methods}

Data collection Claims records from one carrier beginning in January 2006 and ending in December 2015 were reviewed to determine the frequency, severity, and basis of settled claims in litigation in REI. We reviewed claims and settlements over a 10-year interval from 2006 to 2015 . Ten practices were insured during this time interval. Data were extracted from claims files at one insurance company. All practices were staffed by board certified reproductive endocrinologists. All practices had embryology labs with in-house biopsy teams for preimplantation genetic screening (PGS), on site lab directors, and offered full services including surgery, in vitro fertilization (IVF) and PGS, and third party reproductive programs. One hundred eighty-four thousand and fifteen total IVF cycles were performed among these practices within this time interval. Records were reviewed for all claims, allegations, and basis of claims paid. We defined a claim as a written demand for compensation from medical injury. The study was IRB approved through Western IRB.

Review of claims Review was conducted by two administrators/adjudicators and one attorney of the insurer. We sought to identify cases in which indemnity was paid, describe the claims for damages and the amount of indemnity paid. The cases were reviewed and clinical details of the cases with settlement payments and basis for damages extracted from the records review. The records were then summarized without patient identification. Information for claims settled was then summarized under three categories of case description: damages sought and indemnity paid. This summary information was then submitted to the author without identifying information or any additional chart notes. The errors leading to the claims paid were divided into three categories: misdiagnosis and lack of informed consent; surgical complications and embryology laboratory error. The awards are described in amount paid to plaintiff and did not include costs of litigation. Settlements sums are rounded to the nearest $\$ 50,000$.

\section{Results}

There were ten member practices in nine states insured through the carrier. These practices performed a total of 184,015 total IVF cycles. There were 176 incidents over this time interval that peaked in 2010 for unclear reasons and in spite of a stable number of practices and stable practice volumes (Fig. 1). These incidents resulted in indemnity payments in 21 claims. Monetary awards for claims settled during this interval and for the 21 claims totaled $\$ 15,062,000$ with an average settlement claim of $\$ 717,238$. Information extracted from each case included the cause of action, type of damage awards sought and final monetary awards. In terms of settlement award amounts, misdiagnosis and lack of informed consent were highest total amount at $\$ 11,583,000$ and accounted for $76 \%$ of award dollars. The two highest awards were $\$ 4.5$ million and $\$ 3.0$ million for cancer and genetic misdiagnosis, respectively. These award amounts were unusually large for the series studied. Excluding these two awards, indemnity payments for all other claims totaled $\$ 7,562,000$ million and ranged from $\$ 6000$ to $\$ 900,000$ and averaged $\$ 170,363$. In terms of frequency, errors in embryology laboratory were highest and accounted for $38 \%$ of claims paid for a total of $\$ 1,624,000$ and an average claim payment of $\$ 203,000$. Settlements for surgical complications totaled $\$ 1,855,000$ and averaged $\$ 463,750$ per claim. Description of cases with indemnity paid, the damages claimed, and the amount of indemnity paid are listed in Tables 1, 2, and 3. Cases were dispersed across all practices without a preponderance of settlements for any one practice. There were no findings suggestive of a clustering of cases based on practice size or geographic location nor were any single providers identified with recurrent claims.

Claim volume was driven by claims for embryology/ andrology laboratory errors including the loss of sperm, embryos and eggs and lack of success. The severity of the claims in award amount was driven by claims for misdiagnosis and lack of informed consent. A comparison of amount of indemnity paid by claim type was also completed. Forty-four percent of the total indemnity paid resulted from misdiagnosis and lack of informed consent. This was followed by claims involving surgical complications accounted for $26 \%$ of the total indemnity paid.

\section{Discussion}

Medical malpractice claims and litigation are complicated and lengthy processes in which defense and investigations are formulated in response to an event or alleged substandard care $[5,6]$. With increasing awareness of risk profiles, the process has evolved into a practice where standards of care and areas of liability are defined prospectively, prior to an event with the hope of prevention or reduction in any harm. Root cause analysis and risk management have contributed to this changing paradigm and have been instrumental in establishing guidelines to protect patient and provider interests alike [7-9]. In a high-risk environment, the ability to identify areas of vulnerability and opportunities to improve care would be a valuable asset in risk management.

We studied cases and settled claims in the specialty of REI to define risk profiles and to describe areas of vulnerability in REI. 
Fig. 1 Trend in claims filed over a 10 -year period
Claims Per Year (2005/6 -2014/15)

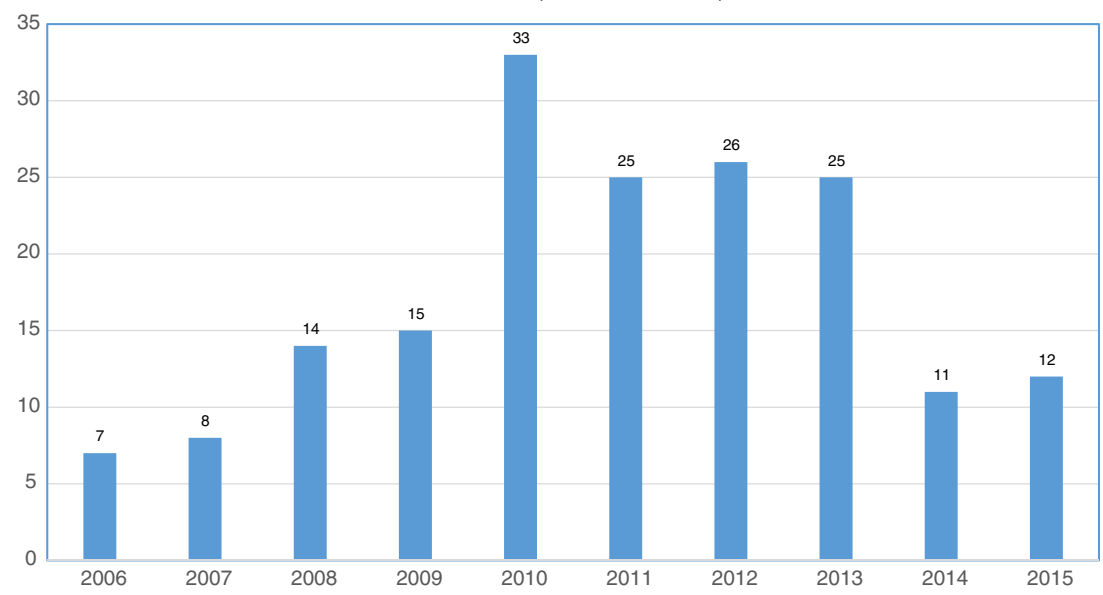

Claims were evaluated from the perspective of size and frequency of settlement. Twenty one settled cases were identified during this 10 year period. Cases involving misdiagnosis and lack of informed consent accounted for the largest settlement awards while cases related to lab error and mishandling of gametes or embryos accounted for the highest frequency of claims settled. These observations offer the opportunity to evaluate areas for improvement and root cause analysis and suggest that claims frequency could be reduced by adjustment of practice patterns in these two areas.

The overall trends in frequency show low levels at the start of the study interval with a gradual peak at 33 between years 2009 10 and persistence until 2012-13. There was a gradual return to lower levels at the conclusion of the study period to 2014-15. This peak incidence of settlements suggests that the claims filing dates may have been 2 to 3 years earlier given the interval from filing to settlement of 2 to 3 years or approximately 2008. This trend corresponds to an interval of significant economic downturn and a possible impact of external and social factors on the claims frequency.

The claims were divided for descriptive purposes into three categories: surgical complications, embryology and lab errors, and misdiagnosis/lack of informed consent. Surgical complications leading to settlements were infrequent but settled at costs above average at $\$ 463,750$ per settled claim owing to a large settlement of $\$ 1,000,000$. Settlements relating to errors in the embryology and andrology laboratory were the most common but lowest average settlement at $\$ 199,187$ per settled claim. Errors leading to these settlements are best described as systems errors or the occasional and unintentional human error and not negligence or the failure to meet a standard level of care. According to an Institute of Medicine paper, most medical errors are in this category and may be reduced through system changes [10]. The data from the current study suggest that augmenting the systems of checks and validations already in place in most labs may reduce this risk scenario. Though at times unavoidable in spite of diligent practice, monitoring frequency of high risk events may be one route to improvement. Although it may be impossible to reduce human error to zero, diligent tracking of events and their frequency remains a worthy goal. A technical report from California by the RAND Institute suggested that decreases in the frequency of adverse events were positively associated with decreases in the volume of malpractice claims [11]. These results extrapolated from clinical care to embryology suggest that policy improved communication of treatment plans

Table 1 Case descriptions, damage claims, and settlements paid for surgical complications

\begin{tabular}{|c|c|c|}
\hline \multicolumn{3}{|l|}{ Surgical complications } \\
\hline $\begin{array}{l}\text { Description of cases with } \\
\text { indemnity paid }\end{array}$ & Damages & $\begin{array}{l}\text { Indemnity } \\
\text { paid }\end{array}$ \\
\hline $\begin{array}{l}\text { Bladder perforation during } \\
\text { surgery for ectopic } \\
\text { pregnancy; failure to } \\
\text { diagnose and treat } \\
\text { post-operative infection in } \\
\text { timely manner resulting in } \\
\text { prolonged hospitalization. }\end{array}$ & $\begin{array}{l}\text { Additional medical } \\
\text { treatment; disfigurement; } \\
\text { pain and suffering; } \\
\text { activities limited to } \\
\text { carrying } 10 \text { lbs. and } \\
\text { requires assistant of } \\
\text { service dog. No lost } \\
\text { wages. Past medical } \\
\text { expenses: } \$ 400,000\end{array}$ & $\$ 1,000,000$ \\
\hline $\begin{array}{l}\text { Failure to properly perform } \\
\text { uterine septum resection } \\
\text { resulting in uterine rupture } \\
\text { during pregnancy. }\end{array}$ & $\begin{array}{l}\text { Need for uterine repair, pain } \\
\text { and suffering; claim that } \\
\text { pregnancy would } \\
\text { endanger the mother; lost } \\
\text { wages } \$ 10,800 \text {; adoption } \\
\text { costs: } \$ 30,000 \text {. }\end{array}$ & $\$ 500,000$ \\
\hline $\begin{array}{l}\text { Bowel perforation during } \\
\text { laparoscopy resulting in } \\
\text { sepsis and colostomy. }\end{array}$ & $\begin{array}{l}\text { Additional medical } \\
\text { treatment; colostomy } \times \\
6 \text { months; disfigurement; } \\
\text { medical expense: } \$ 500 \text {; } \\
\text { lost earnings: } \$ 1680 \text {. }\end{array}$ & $\$ 300,000$ \\
\hline $\begin{array}{l}\text { Failure to diagnose an } \\
\text { abdominal wall infection } \\
\text { resulting in necrotizing } \\
\text { abscess requiring } \\
\text { emergency surgery. }\end{array}$ & $\begin{array}{l}\text { Additional surgical } \\
\text { treatment needed. } \\
\text { Original demand: } \\
\$ 150,000 \text {. }\end{array}$ & $\$ 55,000$ \\
\hline
\end{tabular}


Table 2 Case descriptions, damage claims, and settlements paid for embryology, and laboratory errors

\begin{tabular}{|c|c|c|}
\hline $\begin{array}{l}\text { Description of cases with } \\
\text { indemnity paid }\end{array}$ & Damages & $\begin{array}{l}\text { Indemnity } \\
\text { paid }\end{array}$ \\
\hline $\begin{array}{l}\text { Transfer of four embryos } \\
\text { instead of two resulting in } \\
\text { quadruplet pregnancy. } \\
\text { The patient delivered } 4 \\
\text { premature infants with } \\
\text { survival of three. }\end{array}$ & $\begin{array}{l}\text { Wrongful death; pain and } \\
\text { suffering; hospitalization } \\
\text { for } 3 \text { premature infants: } \\
\$ 60,877 \text {; cost of raising an } \\
\text { additional child. }\end{array}$ & $\$ 900,000$ \\
\hline $\begin{array}{l}\text { Failure to properly handle } \\
\text { embryos resulting in the } \\
\text { loss of high grade } \\
\text { embryos and failure to } \\
\text { become pregnant. }\end{array}$ & $\begin{array}{l}\text { Loss of embryos; emotional } \\
\text { distress; demand } \$ 3 \mathrm{M} \text {. }\end{array}$ & $\$ 60,000$ \\
\hline $\begin{array}{l}\text { Loss of frozen embryos. } \\
\text { Frozen embryos were } \\
\text { inadvertently thawed } \\
\text { absent any uterine prep } \\
\text { without chance of transfer. }\end{array}$ & $\begin{array}{l}\text { Loss of embryos; emotional } \\
\text { distress. }\end{array}$ & $\$ 32,500$ \\
\hline $\begin{array}{l}\text { Accidental loss of embryos } \\
\text { resulting in lost } \\
\text { opportunity to have } \\
\text { children. }\end{array}$ & Loss of 16 embryos. & $\$ 530,000$ \\
\hline $\begin{array}{l}\text { Accidental loss of embryos } \\
\text { resulting in emotional } \\
\text { distress. }\end{array}$ & Loss of 9 embryos. & $\$ 25,000$ \\
\hline $\begin{array}{l}\text { Loss of frozen oocytes. After } \\
\text { initial request to discard } \\
\text { frozen oocytes, patient } \\
\text { retracted request and was } \\
\text { incorrectly assured the } \\
\text { oocytes remained frozen. } \\
\text { When an insemination } \\
\text { and transfer were planned, } \\
\text { it was discovered that } \\
\text { the oocytes had been } \\
\text { discarded at the time of the } \\
\text { intial request to discard. }\end{array}$ & $\begin{array}{l}\text { Medical expenses: } \$ 4420 \text {; } \\
\text { facility's expenses: } \$ 2215 \text {; } \\
\text { Emotional distress, pain } \\
\text { and suffering: } \$ 26,544\end{array}$ & $\$ 20,000$ \\
\hline $\begin{array}{l}\text { Loss of frozen embryo. An } \\
\text { embryo was transferred } \\
\text { from another facility and } \\
\text { was not viable upon thaw. }\end{array}$ & $\begin{array}{l}\text { Economic damages; cost of } \\
\text { additional IVF cycle and } \\
\text { medication: } \$ 15,000 \text { and } \\
\text { oocyte retrieval } \$ 8700\end{array}$ & $\$ 20,000$ \\
\hline $\begin{array}{l}\text { No pregnancy after IVF. The } \\
\text { patient sued for return of } \\
\text { fees after unsuccessful } \\
\text { IVF cycle. }\end{array}$ & Cost of IVF cycle: $\$ 15,000$ & $\$ 6000$ \\
\hline
\end{tabular}

between the lab staff and clinical providers may offer a new avenue for reducing malpractice pressure and eliminating inadvertent lab errors.

Misdiagnosis and errors in diagnosis are among the most costly allegation in medical malpractice [12]. These findings were evident in our review also with average settlement at $\$ 1,353,750$. Claims relating to misdiagnosis and lack of informed consent in REI are rapidly becoming complicated issues as genetics becomes an integral part of the practices [13]. Reproductive genetics marks a significant development in the
Table 3 Case descriptions, damage claims, and settlements paid for misdiagnosis and lack of informed consent claims

Misdiagnosis and lack of informed consent

\begin{tabular}{|c|c|c|}
\hline $\begin{array}{l}\text { Description of cases with } \\
\text { indemnity paid }\end{array}$ & Damages & $\begin{array}{l}\text { Indemnity } \\
\text { paid }\end{array}$ \\
\hline $\begin{array}{l}\text { Carrier screening for CF was } \\
\text { positive but reported as } \\
\text { negative. After IVF, a } \\
\text { child was born with CF. }\end{array}$ & $\begin{array}{l}\text { Wrongful life, wrongful } \\
\text { birth and wrongful } \\
\text { conception; life care plan } \\
\text { totaled } \$ 4 \mathrm{M} \text {. }\end{array}$ & $\$ 2,297,453$ \\
\hline $\begin{array}{l}\text { Failure to diagnose adrenal } \\
\text { cortical carcinoma. The } \\
\text { failure resulted in } \\
\text { advancement of her } \\
\text { carcinoma and metastasis } \\
\text { to her lungs. }\end{array}$ & $\begin{array}{l}\text { Medical bills: } \\
\$ 350,000-\$ 400,000 ; \text { pain } \\
\text { and suffering; disability. }\end{array}$ & $\$ 4,500,000$ \\
\hline $\begin{array}{l}\text { Failure to offer carrier } \\
\text { screening for cystic } \\
\text { fibrosis resulting in a child } \\
\text { born with cystic fibrosis }\end{array}$ & $\begin{array}{l}\text { Life care plan estimated to be } \\
\$ 2-5 \mathrm{M}\end{array}$ & $\$ 900,000$ \\
\hline $\begin{array}{l}\text { Misdiagnosis of intra-uterine } \\
\text { pregnancy as ectopic } \\
\text { pregnancy. Methotrexate } \\
\text { was administered } \\
\text { resulting in the loss of a } \\
\text { viable fetus. }\end{array}$ & $\begin{array}{l}\text { Pain and suffering; Non } \\
\text { economic cap: } \$ 560,000 \text {. }\end{array}$ & $\$ 150,000$ \\
\hline $\begin{array}{l}\text { Failure to offer screening for } \\
\text { Beta Thalassemia } \\
\text { resulting in an affected } \\
\text { child. }\end{array}$ & $\begin{array}{l}\text { Medical expenses: } \$ 9905 \\
\text { emotional distress; lost } \\
\text { wages; } \$ 5 \text { M life care plan }\end{array}$ & $\$ 675,000$ \\
\hline $\begin{array}{l}\text { Failure to treat and lack of } \\
\text { informed consent. Patient } \\
\text { with lupus anticoagulant } \\
\text { undergoing IVF treatment } \\
\text { had a CVA. }\end{array}$ & $\begin{array}{l}\text { Cognitive and psychiatric } \\
\text { impairments; lost wages: } \\
\$ 1,915,932 ; \\
\text { non-economic cap: } \\
\$ 650,000 \text {. }\end{array}$ & $\$ 650,000$ \\
\hline $\begin{array}{l}\text { Failure to inform that the } \\
\text { PGS could not completely } \\
\text { rule out the possibility of } \\
\text { cystic fibrosis. A child } \\
\text { was born with cystic } \\
\text { fibrosis. }\end{array}$ & $\begin{array}{l}\text { Life care plan: } \$ 2.5-\$ 5.5 \mathrm{M} \text {; } \\
\text { lost wages, emotional } \\
\text { distress. }\end{array}$ & $\$ 625,000$ \\
\hline $\begin{array}{l}\text { Failure to submit an } \\
\text { endometrial polyp for } \\
\text { histologic evaluation; } \\
\text { failure to diagnose } \\
\text { endometrial } \\
\text { adenocarcinoma that } \\
\text { resulted in death. }\end{array}$ & $\begin{array}{l}\text { Lost wages; pain and } \\
\text { suffering; and household } \\
\text { earnings: } \$ 748,771 \text {. } \\
\text { Non-economic cap for } \\
\text { case: } \$ 1,065,500\end{array}$ & $\$ 925,000$ \\
\hline $\begin{array}{l}\text { Failure to accurately report } \\
\text { positive PGD result. The } \\
\text { patient was pregnant with } \\
\text { an affected fetus which } \\
\text { they elected to voluntarily } \\
\text { terminate. }\end{array}$ & $\begin{array}{l}\text { Loss of 4-month-old fetus; } \\
\text { medical expenses: } \\
\$ 20,000 \text {; emotional dis- } \\
\text { tress. }\end{array}$ & $\$ 105,000$ \\
\hline
\end{tabular}

field of ART with unique obligations and physician liabilities derive from these options. PGS is emerging as a standard of care with unique liabilities and the risk that claims may be made for long-term care with sizeable settlement awards [14, 15]. Deeper informed consent including opt-in and opt-out counseling 
regarding PGS and computer assisted counseling tools may improve communication and reduce liability. Failure to disclose the limitations of the technology in PGS including the possibility that the testing could be a false negative could leave patients with false assurances about the health of their embryos. This false assurance could raise informed consent liability issues particularly if a child is born with a disability as a result. Online tools for enhanced counseling (https://engaged-md.com/) and patient specific success rates (https://www.polaris-platform.com/) are available and may offer a standardized, uniform method to counsel and document consent.

The average settlement in REI in this series per claim payment of $\$ 717,238$ is higher than average claims in other specialties. In one review, the overall average was $\$ 485,348$ per claim paid. In another stratified by severity, costs per claim payment averaged $\$ 386,849$ and higher for major and serious complications with settlement costs at $\$ 419,711$ and $\$ 808,591$, respectively [16]. These claims paid do not include costs of defense which could be significant and add to the overall cost of malpractice insurance. Our data suggest that for the 10-year interval studied, claims frequency is relatively low especially in contrast to other specialties with rates of claims as high as $40 \%$. Misdiagnosis is the most costly consistent with prior studies and liability related to lab occurrences are the most frequent causes of claims. The average cost for claims settled in REI is higher than average for other medical specialties. This risk profile may change as practices expand the use of reproductive genetics where claims and indemnity payments may increase as long term care is added to the liability profiles.

Two aspects of this study require comment. This analysis is from a single carrier with a limited number of practices. These practices however include the full spectrum of services in most infertility practices nationally. We chose as our primary outcome the number of claims settled and the amount paid. Most previous studies in medical malpractice have analyzed all claims where $70 \%$ of all claims do not result in payments. This is not to ignore the significance of claims that do not result in payments which can be frustrating for plaintiff and defendant and costly to bring and defend. We contend that paid claims may be more informative than unpaid claims [17, 18]. Although payment does not necessarily indicate that a claim has merit, paid claims are much more likely than unpaid claims to involve substandard care [19]. This perspective is not to underestimate the impact of all claims on providers and insurers. Acknowledgements The author declares no financial support from any
sources.

\section{Compliance with ethical standards}

Conflict of interest The author declares that he has no conflict of interest.

\section{References}

1. Mac Court D, Bernstein J. Medical error reduction and tort reform through persistent controllably level quality medicine societies. Am J Law Med. 2009;35:505-61.

2. Kravitz RL, Rolpf JE, McGuigan K. Malpractice claims data as a quality improvement tool: epidemiology of error in for specialties. JAMA. 1991;266:2087-9.

3. Van Noord I, Eikens MP, Hanersma AM, Bruijne MC. Application of root cause analysis on malpractice claim files related to diagnostic failures. Qual Saf Health Care. 2010;19(6):e21.

4. Spittel MJ, Bismark MM, Studdert DM. The PRONE score: an algorithm for predicting doctors risks of formal patient complaints using routinely collected administrative data. BMJ Qual Saf. 2015;24:360-8.

5. Sohn D. Negligence, genuine error and litigation. Int J Gen Med. 2013;6:649-56.

6. Stamm JA, Korzick KA, Beech K, Wood KE. Medical malpractice: reform for today's patients and clinicians. Am J Med. 2016;129(1):20-5.

7. Latino RJ. How is the effectiveness of root cause analysis measured in healthcare? J Health Risk Manag. 2015;35(2):21-30.

8. Khorsandi M, Beatson K, Alijani A. Quality review of an adverse incident reporting system and root cause analysis of serious adverse surgical incidents in a teaching hospital of Scotland. Patient Saf Surg. 2012;6:21. doi:10.1186/1754-9493-6-21. Published online 2012 Aug 29.

9. Heideveld-Chevalking AJ, Calsbeek H, Damen J, Gooszen H, Wolff AP. The impact of a standardized incident reporting system in the perioperative setting: a single center experience on 2,563 'near-misses' and adverse events. Patient Saf Surg. 2014;8(1):46.

10. Warm D, Edwards P. Classifying health information technology patient safety related incidents - an approach used in Wales. Appl Clin Inform. 2012;3(2):248-57. doi:10.4338/ACI-2012-03-RA-0010.

11. Institute of Medicine. In: Kohn LT, Corrigan JM, Donaldson MS, editors. To err is human: building a safer health system. Washington, DC: National Academy Press; 1999.

12. Wachter RM, Pronovost PJ, Shekelle PG. Strategies to improve patient safety: the evidence base matures. Ann Intern Med. 2013;158(5):350-52, part 2, Editorial, W-173. Posted on RAND.org on March 01, 2013.

13. Graber ML. The incidence of diagnostic error in medicine. BMJ Qual Saf. 2013;22 Suppl 2:ii21-7. doi:10.1136/bmjqs-2012001615.

14. Crockin SL. Reproduction, genetics and the law. Reprod BioMed Online. 2005;10(6):692-704.

15. Amagwula T, Chang PL, Hossain A, Tyner J, Rivers AL, Phelps JY. Preimplantation genetic diagnosis: a systematic review of litigation in the face of new technology. Fertil Steril. 2012;98:1277-82.

16. Wilton L, Thornhill A, Traeger-Synodinos J, Sermon KD, Harper JC. The causes of misdiagnosis and adverse outcomes in PGD. Hum Reprod. 2009;1:1-8.

17. Lee H, Mathews SC, Shore A, Makary MA, Pronovost PJ, Newman-Toker DE. 25-Year summary of US malpractice claims for diagnostic errors 1986-2010: an analysis from the National Practitioner Data Bank. BMJ Qual Saf. 2013;22(8):672-80. doi: 10.1136/bmjqs-2012-001550.

18. Studdard DM, Mello MM, Gawande AA, et al. Claims errors and compensation payments in medical malpractice litigation. NEJM. 2006;354:2024-33.

19. Brennan T, Sox CM, Burstin HR. Relation between negligent adverse events in the outcomes of medical malpractice litigation. NEJM. 1996;335:1963-7. 